\title{
The Role of Engineers as Policy Entrepreneurs toward Energy Transforma- tions
}

\section{Prof. Efrain O’Neill-Carrillo, University of Puerto Rico, Mayaguez Campus}

Efraín O'Neill-Carrillo is a professor of power engineering at the University of Puerto Rico, Mayagüez (UPRM). He holds a Ph.D. (Arizona State), an M.S.E.E. (Purdue), and a B.S.E.E. (UPRM). His professional interests include energy policy, sustainable energy, distributed generation, power quality, social and ethical implications of engineering, and technology. He has authored or co-authored more than 60 peer-reviewed journal and conference papers. O'Neill-Carrillo was the founding Director (2007-2010) of the Institute for Tropical Energy, Environment, and Society, leading a group of 15 professors from 10 disciplines in establishing links between energy research and society while influencing energy policy in Puerto Rico (http://iteas.uprm.edu/). O'Neill-Carrillo was also the Education Coordinator at UPRM for the NSF's Center for Power Electronics Systems (CPES) from 2000-2008. He was Associate Director, CIVIS: Center for Resources in General Education, assisting in the administration of the Center, as well as developing student learning modules (sustainability, ethics), a sustainable energy initiative and coordinating the interaction and work of professors from various disciplines in UPRM (2008-2013). He has been energy Advisor for city governments and state agencies in Puerto Rico. O'Neill was Senior Advisor to the Governor of Puerto Rico on Energy (2013-2014). He is one of the authors of the study "Achievable Renewable Energy Targets for Puerto Rico's Renewable Portfolio Standard," presenting the potential of renewable energy in Puerto Rico (http://www.uprm.edu/aret). He is also very active in the energy policy debate in Puerto Rico, authoring "Una Nueva AEE," a Spanish document that traces the history of the Puerto Rico Electric Power Authority, presenting potential reforms to the Island's electric system (http://iteas.uprm.edu/recursos.php). O'Neill-Carrillo is a founding member of the Puerto Rico Electric Energy Round Table, a multi-sector group that works on technical and policy alternatives for the future of Puerto Rico's electric system, acting as the Group Coordinator from 2008 to 2010. He is a Senior Member of IEEE, an ABET Program Evaluator and a registered Professional Engineer. His views and work on integrative research and education activities, and his professional service have earned O'Neill-Carrillo UPRM's Outstanding ECE Professor of the Year Award (twice), the Distinguished Electrical Engineer of the Year Award from the CIAPR in May 2004, an Early Promotion to Full Professor from UPRM in Nov. 2004, and the IEEE/PES Walter Fee Outstanding Young Engineer Award in June 2005.

\section{Dr. Agustin Irizarry-Rivera P.E., University of Puerto Rico, Mayaguez Campus}

Agustín Irizarry-Rivera is professor of electric power engineering at the University of Puerto Rico, Mayagüez (UPRM). He holds a Ph.D. (Iowa State), an M.S.E.E. (Univ. of Michigan-Ann Arbor), and a B.S.E.E. (UPRM). He conducts research in the topic of renewable energy and how to adapt the existing power grid to add more of these resources in our energy portfolio. He has served as Consultant on renewable energy and energy efficiency projects to Puerto Rico's Government agencies, municipalities, private developers and consulting firms in and outside Puerto Rico. He has also served as expert witness in civil court cases involving electric hazard, shock or electrocution. He is author or coauthor of over 40 refereed publications including two book chapters. A licensed professional engineer in Puerto Rico since 1991 and member of IEEE he has organized local and international conferences such as the Tenth International Conference on Probabilistic Methods Applied to Power Systems (PMAPS 2008) in Rincón, Puerto Rico. Dr. Irizarry-Rivera has received several awards and honors: Distinguished Engineer 2013 from Puerto Rico's Professional Engineers Society (CIAPR) and Distinguished Electrical Engineer 2005 from the Electrical Engineering Institute of CIAPR in recognition of services rendered to the profession and outstanding professional achievements in electrical engineering, the 2009 Distinguished Alumni Award from UPRM Alumni Association, the 2004 Professional Progress in Engineering Award from Iowa State University, in recognition of outstanding professional progress and personal development in engineering as evidenced by significant contributions to the theory and practice of engineering, distinguished service rendered to the profession, appropriate community service, and/or achievement in a leadership position and the 2003-2004 ECE Outstanding Faculty Award from UPRM's School of Engineering. In May 2012 
he was elected, by the consumers, to the Board of Directors of the Puerto Rico Electric Power Authority, in the first election of this kind in Puerto Rico, to represent the interests of consumers. He was President of the Board's Audit Committee and an active member of the Engineering and Infrastructure, Legal and Labor Affairs and Consumer's Affairs Committees. In 2013 Board Members elected him Vice President of the Board and he served in this capacity until September 2014 when his term expired.

\section{Dr. Cecilio Ortiz, University of Puerto Rico-INESI}

Dr. Cecilio Ortiz Garcia is Associate Professor of Political Science at the University of Puerto RicoMayaguez. He holds a PhD in Public Policy and Administration from the Arizona State University School of Public Affairs and specializes in issue related to the public administration of natural resources and the environment, energy policy and governance and the social acceptance of renewable energy technologies. Dr. Ortiz is also a member of the Steering Committee and co-founder of the National Institute of Energy and Island Sustainability of the University of Puerto Rico (INESI).

\section{Dr. Marla D. Perez-Lugo, University of Puerto Rico, Mayguez Campus}

Marla D. Perez-Lugo is an environmental sociologist at University of Puerto Rico at Mayaguez (UPRM). Her research focuses on environmental justice and public participation issues related to the design and implementation of renewable energy projects in Puerto Rico. She is currently a member of the steering committee of the National Institute of Energy and Island Sustainability of the UPR system. 


\section{The Role of Engineers as Policy Entrepreneurs}

\section{towards Energy Transformations}

ABSTRACT - In the early 1990's engineering professors at the University of Puerto RicoMayaguez (UPRM) began broadening their scope of actions by actively promoting and supporting novel and alternative energy options within professional societies, and among policy makers and government officials (local and state). This paper presents recent initiatives to continue this policy effort and the progression of the involvement of two engineering professors and their students in energy policy education, creation and evaluation using sustainable energy as the focus. Collaborations with Social Sciences professors were essential as well as the creation of a university energy institute. Courses on energy policy and social/ethical issues delivered to graduate and undergraduate students are described, including a synchronous web delivery of the policy course to law students. The energy policy entrepreneurship was taken to the real world with the creation and leadership of a multi-sector energy stakeholders roundtable, through renewable energy projects in communities and participation in energy-related public hearings with graduate and undergraduate students. The engineering professors delved even further into the energy policy process by participating in the governing board of the largest electric utility in Puerto Rico and as advisors to the Governor. Policy actions from engineering professors and students played an important role in the passing of a comprehensive electric sector reform in May 2014. The paper also presents university education efforts (supported by a DOE grant) that provide the electricity sector workforce and stakeholders with tools and knowledge needed to implement the reform mandated by law. The paper concludes with assessment results from a new course created once the professors returned to UPRM, a reflection on the background required for effective energy policymaking participation, and a summary of lessons learned from these policy experiences.

\section{Introduction}

Policy entrepreneurs promote significant policy change, and usually: have social acuity, define problems, build teams and lead by example ${ }^{1}$. Entrepreneurs "... wait in and around government with their solutions (already) in hand, waiting for problems to float by to which they can attach their solutions, waiting for a development in the political stream they can use to their advantage" ${ }^{2}$. The policy agenda setting process "is one of choices looking for issues, problems looking for decision situations, solutions looking for problems, and politicians looking for pet problems or policies by which they might advance their careers" ${ }^{2-3}$. There are negative definitions of policy entrepreneurs, such as "peddlers of politically popular but academically wrong ideas" " or "individuals that exploit an opportunity in order to influence political results and promote a political agenda that promotes their business interests" 5 . Despite this negative, self-centered view of policy entrepreneurs, there is a robust policy literature that uses the more positive definition of policy entrepreneurs as actors that promote innovation in government agendas. Early references to policy entrepreneurship date back to $1981^{6}$ and the 1984 definition in Kingdon's book ${ }^{2}$. Although there are references that use the policy entrepreneurship framework to describe sustainability transitions ${ }^{7}$, and water management ${ }^{8}$, there are limited applications in the energy area.

This paper presents the role of engineers from the University of Puerto Rico-Mayaguez (UPRM) as policy entrepreneurs in the area of sustainable energy. By considering the actions of engineers 
in the fields of "disruptive energy innovation" important insights can be gained into the process of energy policy innovation and innovation diffusion. The presence and actions of engineers can significantly alter the framing of energy issues, raise the probability of legislative consideration and approval of policy innovations, and can ultimately broaden the policy horizon for energy transitions and transformations to more sustainable and distributed energy technologies and strategies. The concept of policy entrepreneurs is used to describe early efforts as well as more recent instances where UPRM engineering professors and their students, actively promoted energy policy changes.

Collaborations with Social Sciences professors were vital as well as the creation of a university energy institute. The discussion includes a description of a traditional university-based consulting effort for a state agency that had key participation from graduate students. New courses on energy policy and on social and ethical issues delivered to graduate and undergraduate electrical engineering students are described, including a synchronous web delivery of the policy course to law students. The energy policy entrepreneurship was taken to the real world with the creation and leadership of a multi-sector energy roundtable, and energy projects in communities. The paper focuses on sustainable energy applied to electric energy systems (in particular power distribution topics such as distributed generation and net metering), and the role of engineers in the formulation and enforcement of public policy. Although the scope of this paper is mostly related to electrical engineering and social sciences, the lessons learned are applicable to policy work in other disciplines relevant to sustainable energy, such as mechanical engineering, chemical engineering, and business administration among others.

\section{Energy Policy Framework}

UPRM has led many key energy initiatives as the state's land grant college in areas such as academic programs, energy research and service (mainly in the form of energy consulting). Most stakeholders perceive UPRM as an objective entity that provides advice when requested. In the early 1990's engineering professors began broadening their scope of actions by actively promoting and supporting novel and alternative energy options within professional societies, and among policy makers and government officials (local and state). A salient example was Dr. José Colucci (formerly with UPRM's Chemical Engineering Department) who championed various energy initiatives in Puerto Rico such as biofuels, the use of fuel cells, multi-sector energy collaborations (university, industry and government) and forums to openly discuss polarizing energy topics such as waste to energy technologies. He was the leader of the project that for the first time successfully used biodiesel by industry, university and government (showing the feasibility of a biodiesel industry in the Island). Without knowing it, Dr. Colucci was working as an energy entrepreneur, laying the groundwork for some of the energy policy work described in this paper.

In the early 2000's a group of UPRM engineering and social sciences professors came to the agreement that energy problems and issues were not only technical in nature but sociotechnical. The electrical system needs to be understood as a system constituted by physical and social components. This idea was the basis for proposals written in 2003 and 2004. The Institute for Tropical Energy, Environment and Society (ITEAS by its acronym in Spanish (ITEAS) emerged from those efforts at UPRM to address in a multidisciplinary form the complexities of energy problems and to develop sustainable public policy alternatives for Puerto Rico. Some of the disciplines represented in ITEAS are: engineering, sociology, public policy, biology, marine 
sciences, and agricultural sciences among others. ITEAS quickly gained recognition and legitimacy within Puerto Rico. Since 2007 ITEAS has been striving to elevate the debate of future power systems from mostly technological matters to a comprehensive and sustainable look that merges environmental, social and economic considerations while using a multi-sector approach ${ }^{9}$, ${ }^{10}$. All authors of this paper are members of the Executive Committee of ITEAS. Dr. O'Neill (ITEAS first Director) and Dr. Irizarry are engineering professors; Dr. Pérez and Dr. Ortiz are social science professors that have been ITEAS leaders on public policy. Their capacity building work has proven to be essential in the emergence of engineers as policy entrepreneurs from ITEAS.

ITEAS research efforts in sustainability concentrate on how to effectively influence the current energy policy regime to promote the sustainable utilization of renewable energy sources. ITEAS argues that a decision making process based on the principles of sustainability must be designed, operationalized and maintained with the local context in mind. Immersed inside the federal intergovernmental framework, Puerto Rico provides fertile ground to explore the local context of decision-making processes, and the impact that socio-economic, political and cultural characteristics have in fostering or hindering sustainability. To do that, ITEAS follows Lindquist Typology of Policy Influence ${ }^{11}$ through:

- Expanding Policy Capacities of Stakeholders: Improving the knowledge/data of stakeholders; supporting the development of innovative ideas; improving capabilities to communicate ideas; and developing new talent for research and analysis.

- Broadening the Energy Policy Horizon: Providing opportunities for networking/learning within the jurisdiction or with colleagues elsewhere; introducing new concepts to frame debates, putting ideas on the agenda or stimulating debate; educating researchers and others to take up new positions with broader understanding of renewable/energy issues; and stimulating dialogue amongst decision-makers.

- Affecting the Energy Policy Regime: The modification of existing energy policy in Puerto Rico; and fundamental redesign of its major components

This typology was tested within ITEAS in the training of faculty, including engineering professors. This also constitutes the overall framework of the endeavors described in the remainder of the paper. The main focus of the work in ITEAS has been Puerto Rico's electric power system.

\section{A Multi-Sector Approach}

The future of electric energy systems is usually discussed from a technological perspective or basis; e.g., the future is a smart grid, or the future is a green grid. Many times the discussion of technological options precedes a more fundamental question: what is the future electric power grid for? People are usually looked at as consumers, and at most, as participants in market-based demand management programs. Usually consumer behavior is equated to how much electric power particular segments of the population demand and at what times of the day. Nevertheless, as business literature points out, the expectations of informed and connected people have dramatically changed. People demand more engagement with providers of goods and services, 
with their employers, and with their government. Likewise, social science literature suggests that a constructivist approach, emphasizing the integration of perspectives from different societal groups can positively affect policy design and outcomes particularly when dealing with complex problems such as the future of electric energy systems.

With this perspective in mind in 2007 the authors organized and participated in a 2-day conference at UPRM entitled "We agree on Renewable Energy, but now what?" with participants from Puerto Rico, Spain and Hawaii. One of the main findings of the conference was the need to establish a forum where energy stakeholders could present their concerns and opinions about the Island's energy future. That was a significant milestone in the work towards a more comprehensive energy policy effort at UPRM that could truly yield energy transformations in Puerto Rico.

On May 2008 ITEAS convened a multi-sector panel composed of the main electric energy stakeholders in Puerto Rico: the PR Electric Power Authority (PREPA, the only electric utility in the Island), the PR Energy Office, PREPA's largest labor union, Misión Industrial (an environmental/community NGO), the PR Manufacturer's Association (the largest industrial trade organization) and ITEAS. The topic of discussion was a legislation that included wheeling of power, the use of the electric infrastructure for the sale of electricity among private parties. That specific topic opened a window for a more broader and important question: what kind of electric grid is needed in Puerto Rico? All panelists expressed their willingness to collaborate with other sectors to improve the electric system. ITEAS hosted a more informal discussion over lunch, which resulted in a commitment from all panelists to continue the energy dialogue. The result was the creation of a Multi-Sector Roundtable on Puerto Rico's Electric System ${ }^{16}$. Dr. O'Neill was the first Coordinator of this group.

Through a combination of theoretical knowledge from UPRM, practical knowledge from environmental, labor and community organizations, and business ideas from the industrial sector, the Roundtable was able to identify common ground that has influenced the public debate providing an agenda for change in the electric sector in Puerto Rico. This multi-sector energy dialogue group presented in December 2009 its strategic plan for the future of the electric system. In 2010 the group convened a National Dialogue on Energy, expanding its membership to include other community groups, and professional organizations. During 2011 the group spearheaded a public education effort regarding a new way to elect the two consumer representatives for the Governing Board of the electric utility. PREPA is a state-owned public power company, and although the Governor selected 7 of the 9-member Governing Board, PREPA operated autonomously from the state government. The remaining two members of the Board were representatives elected by the consumers. The Roundtable got two of its members included in the final ballot for the elections held in January 2012. These two persons were eventually elected, in a very contentious election, and began their terms as representatives of the public on June 2012. Part of that experience is described in a latter section.

\section{University Courses}

ITEAS policy framework (capacity building and policy horizon broadening), and the experiences in the Energy Roundtable enabled the engineering professors (Dr. O'Neill and Dr. Irizarry) to integrate policy into their teaching. A graduate course on renewable energy served as an initial 
platform to introduce engineering students to energy policy issues. Although the course mainly deals with energy sources and technologies, it also includes a discussion of interconnection issues. Interconnecting variable generation to a grid designed for fossil fuels raises important technical questions that many times are bounded by guidelines from policymakers. Thus, the door was opened and motivated new courses to address these issues.

Two graduate courses were taught at UPRM's electrical engineering department that provided new ways to connect "technical" content with the social context in which engineering is practiced. A course on energy policy was taught twice (2008 and 2009), to graduate and undergraduate electrical engineering students. The course was synchronously delivered to law students at another UPR campus in San Juan. A law professor participated at the other campus, teaching law concepts, while Dr. O'Neill taught the engineering topics. Invited lectures complemented the course with topics on policy, environment and administrative issues of energy. The topics of the course "Public Policy in Electrical Engineering" are listed in the Table I. The course presented the history, present state and future of public policy with emphasis in the areas of energy and telecommunications. It also served as an introduction to regulatory processes from a legal and engineering perspective.

Students completed two projects as part of the course. Some of the project topics were:

- Externalities of energy

- Net metering

- Distributed photovoltaic generation: Prospects and policy

- Subsidies, incentives and renewable energy

- Deregulation of the state electric power sector

- Smart grid

The course had an important impact since some of the students went on to participate as policy entrepreneurs: legislative assistants, utility employees and renewable energy consultants in Puerto Rico's electricity sector from 2009 to 2014. Another important outcome of that course was the participation of graduate and undergraduate students in public hearings related to net metering regulations proposed by PREPA in 2008. The utility had an initial draft of the regulations that was too restrictive, and would have hindered the ability of industrial, commercial and residential clients to install renewable energy systems for their own use. In the end, the changes made to the proposed regulation were attained in part due to the participation of students and professors in the public hearings since they provided key technical information, from engineering and social sciences. The policy horizon was broadened through that experience and an important energy transformation began in Puerto Rico: consumers turned to active participants by generating their own power and selling excess electric energy to the power grid.

Rubrics were used to determine if students had met each of the course's main objectives. These rubrics were used on the final projects that students completed each time the course was offered (2008 and 2009). Table II shows the aggregated assessment results, proving the effectiveness of the course.

A second policy related graduate course was taught to engineering students at UPRM. The course (on social, ethical and global issues in electrical engineering) provided a broad 
perspective of the engineering profession, and allowed students to understand the social implications of electrical engineering especially in the areas of communication systems, energy electronic devices and engineering research. It also provided an introduction to ethical issues, responsible conduct of research (RCR), and the relationship of electrical engineering-related industries and communities. Students taking the course complied with the RCR training requirement from NSF and NIH. Sustainability was presented as a pathway to seek a balance among electrical engineering technologies, companies, social and global implications. Invited lecturers from social sciences and humanities complemented the work in class. Table III presents the topics of the course.

Table I. Topics for the course "Public Policy in Electrical Engineering"

\begin{tabular}{|l|c|}
\hline \multicolumn{1}{|c|}{ Outline } & Contact Hours \\
\hline Overview of legal concepts & 1 \\
\hline Sustainability & 6 \\
\hline Government regulation & 4 \\
\hline Rates & 4 \\
\hline Public Policy (state and federal) & 4 \\
\hline Electric Energy & 3 \\
\hline Markets: History, restructuring, competition, federal laws & 13 \\
\hline Transportation & 3 \\
\hline Environmental issues & 3 \\
\hline Telecommunications & 3 \\
\hline Exam & 1 \\
\hline Total hours & 45 \\
\hline
\end{tabular}

Table II. Attainment of course objectives for "Public Policy in Electrical Engineering"

\begin{tabular}{|c|c|c|}
\hline Assessment Question & Results (2008) & Results (2009) \\
\hline $\begin{array}{c}\text { Study of the regulatory processes } \\
\text { from a legal and engineering } \\
\text { perspective (with emphasis on } \\
\text { telecommunications and energy) }\end{array}$ & $87 \%$ & $83 \%$ \\
\hline $\begin{array}{c}\text { Understand the public policy } \\
\text { process in PR and USA }\end{array}$ & $81 \%$ & $85 \%$ \\
\hline $\begin{array}{c}\text { Understand the forces that shape } \\
\text { and influence public policy }\end{array}$ & $89 \%$ & $80 \%$ \\
\hline $\begin{array}{c}\text { Search and apply engineering- } \\
\text { related literature on public policy }\end{array}$ & $86 \%$ & $80 \%$ \\
\hline
\end{tabular}

Assessment results are shown in Table IV. The students met each of the course's main objectives except for one. Some students had trouble applying the ethical canons of IEEE, although they understood well those from the state society of professional engineers (CIAPR by its acronym in Spanish). This reflects the fact that more time was devoted to study the CIAPR code than the IEEE code. It was assumed that after discussing one code, students would be able to study the other on their own. However some students needed more guidance with the IEEE code. 
These courses were not only beneficial to the students; the professor acquired valuable insights that were later used in policy entrepreneurial actions. The courses also served as initial efforts to formalize policy instruction within UPRM's electrical engineering curriculum, and were key capacity building efforts.

Table III. Topics for the course "Social, Ethical and Global Issues in Electrical Engineering"

\begin{tabular}{|l|c|}
\hline \multicolumn{1}{|c|}{ Outline } & Contact Hours \\
\hline $\begin{array}{l}\text { History of Electrical Engineering and The Engineer of } \\
2020\end{array}$ & 3 \\
\hline $\begin{array}{l}\text { Discussion of the codes of ethics from IEEE and CIAPR. } \\
\text { Responsible conduct of research (RCR, as required by } \\
\text { NSF \& NIH). Ethical aspects in EE research, } \\
\text { communication systems, energy, manufacturing and } \\
\text { electronic devices. }\end{array}$ & 13 \\
\hline $\begin{array}{l}\text { Social and global context of the electrical engineering } \\
\text { profession. Governmental and legal issues related to EE. }\end{array}$ & 8 \\
\hline $\begin{array}{l}\text { Community and business } \\
\text { a. Stakeholder engagement and community involvement } \\
\text { b. Corporate responsibilities } \\
\text { c. Management, leadership and social networking }\end{array}$ & 10 \\
\hline $\begin{array}{l}\text { Sustainability and EE: Definitions, frameworks and } \\
\text { economic development }\end{array}$ & 9 \\
\hline Exam & 2 \\
\hline Total hours & 45 \\
\hline
\end{tabular}

Table IV. Attainment of course objectives for "Social, Ethical and Global Issues in Electrical

\begin{tabular}{|c|c|}
\hline \multicolumn{2}{|c|}{ Engineering" } \\
\hline $\begin{array}{c}\text { Define responsment Question conduct of research } \\
\text { and compare to research ethics }\end{array}$ & Results \\
\hline $\begin{array}{c}\text { Understand and apply the ethical canons } \\
\text { from the IEEE and CIAPR (State Society } \\
\text { of Professional Engineers) }\end{array}$ & $63 \%$ \\
\hline $\begin{array}{c}\text { Compare ethical situations } \\
\text { in EE contexts }\end{array}$ & $81 \%$ \\
\hline Analyze ethical problems & $81 \%$ \\
\hline $\begin{array}{c}\text { Solve ethical problems } \\
\text { of EE-related fields }\end{array}$ & $81 \%$ \\
\hline $\begin{array}{c}\text { Examine the global impact } \\
\text { of EE-related fields }\end{array}$ & $100 \%$ \\
\hline $\begin{array}{c}\text { Define sustainability and be able to apply } \\
\text { it to EE-related work }\end{array}$ & $87 \%$ \\
\hline
\end{tabular}




\section{Outreach Projects}

One thing is to "talk policy" and another is to shape, influence and execute policy. Policy is not only achieved through legislation. The social sciences literature is filled with examples of communities that assumed leadership roles and their actions promoted and resulted in policy changes. Dr. O’Neill actively collaborated in a University Institute for Community Development (UICD) at UPRM. The UICD has been involved in service learning projects with communities in Puerto Rico since 2002. Eight undergraduate electrical engineering students participated in three different capstone projects related to improving water service in rural communities, in particular improving the electrical system for the pump that takes water from the community well. In one of the projects, the team included students from Electrical, Mechanical, and Civil Engineering, as well as Surveying and Biology students, and students from Purdue University ${ }^{15}$. Acting as Faculty mentor in the UICD broadened the policy horizon of Dr. O'Neill and was an invaluable capacity building experience that helped in future policy work.

Another example of a community-based project is the photovoltaic (PV) laboratory at Casa Pueblo, in Adjuntas (a mountainous town in South-Central Puerto Rico). Casa Pueblo is an environmental and community NGO that promotes community self-reliance, and is committed to protect the natural, human and cultural resources in the Island. Dr. O'Neill and Dr. Irizarry worked as presenters in outreach efforts organized by Casa Pueblo. The idea to create a model for energy autonomy was born through that collaboration in 2007. The collaboration made the local news, and was part of the public pressure for the utility to accept the interconnection of small renewable systems through net metering in 2008. In August 2008 the PV system in Casa Pueblo became the first net-metered system formally connected to the electric power grid. The collaboration included the installation of a PV system but also community education program hosted by Casa Pueblo. Various undergraduate students as well as two graduate students actively participated of the activities at Casa Pueblo. One of the graduate students based his thesis on the technical feasibility analysis as well as the social benefits of the connection of distributed PV systems such as Casa Pueblo's ${ }^{12}$. The Casa Pueblo laboratory earned the electrical engineering project of the year award from the State Society of Professional Engineers (CIAPR by its acronym in Spanish). This outreach collaboration at Casa Pueblo was one of the first instances in influencing the energy policy regime, and actively promoting the transformation of the electric power sector.

Other policy outreach activities have included capacity building seminars for communities in the Northern end of the state, and demonstrations to high school students. Graduate and undergraduate students have been key resources in those outreach activities as well.

\section{Renewable Energy Projects}

While the work in ITEAS was starting, more traditional university-based engineering consulting efforts where conducted by Dr. O'Neill and Dr. Irizarry. Caguas, a city in the eastern side of the Island had been a long-time collaborator of UPRM mainly through Dr. José Colucci. This triad of professors worked on recommendations on renewable energy, energy efficiency and conservation for the City of Caguas. 


\section{A. Caguas Renewable Energy Showcase}

In 2006-2007 the Mayor of Caguas commissioned a study to determine energy strategies for a more sustainable city. Specific objectives were:

- Conduct field studies to gather data and build Caguas' energy profile.

- Identify high impact opportunities that provide a best match between needs and strategies/technologies (following the city's energy profile).

- Provide a timeline for the implementation of recommendations, including the percentage contribution from each proposed recommendation.

- Present demonstrative, high-visibility project proposals for the governmental, industrial, commercial and residential sectors.

In the final report, the researchers established clearly the need to go beyond the technological and economic solutions, towards a more integrated perspective that considered also the environmental and social implications of the proposals.

Some of the proposed projects were implemented in a second phase of the collaboration with a total investment of \$2 million. For example, after an open call for participants in a residential area of Caguas, forty persons agreed to participate in a pilot program to install photovoltaic (PV) systems and solar water heaters on their home rooftops. That way, those residents turned part of their community into the first PV community in Puerto Rico, connected to the grid through net metering. To this date, that neighborhood remains one of the top residential sectors in terms of density of PV systems in the Island. Caguas included some social aspects in this project through their community outreach office.

\section{B. Achievable Renewable Energy Targets}

The experience with the Caguas Energy Showcase motivated the Puerto Rico energy office to request assistance to UPRM in estimating the potential of each renewable energy resource in the Island for electricity production, which could be used to determine achievable renewable energy targets (ARET). Dr. Irizarry, Dr. Colucci and Dr. O'Neill led a research study that included these resources: biomass, micro hydro, ocean, solar radiation and wind. The work included realistic constraints such as: estimated availability of each resource, estimated required surface area or "foot print", seasonal cycles, state of available technology (commercial or prototype) and estimated capital costs. Seven UPRM graduate students participated in this project, all of them using this experience as part of their Master's thesis.

After the initial phase, the agency requested a more detailed estimate for ocean, solar (photovoltaic) and wind resources. This estimate included: weather effects, day/night cycles, state of available technology (commercial, prototype or laboratory available), costs such as capital investment (including retrofitting of existing facilities), maintenance and operation, electric grid interconnection issues, and other areas as needed to study each resource in detail. A main conclusion was that Puerto Rico has abundant renewable energy resources, and the main challenge is not how to best integrate renewable resources into the existing electric energy grid, 
but how the electric energy grid should change or transition in order to allow maximum use of solar, wind, ocean and other renewable energy sources.

Nevertheless, the researchers made clear that even though the resources and technological knowhow is present, there were no inclusive and open dialogue spaces to reach historic decisions in Puerto Rico. There was a need to "stop thinking within the bounds of our disciplinary or sector limits, start considering the bigger picture and identifying the connections and implications of our decisions into other areas or sectors" $"$.

Rooftop photovoltaic (PV) systems were identified in the ARET study as the main strategy to pursue to increase renewable energy use in the Island. A contribution towards addressing part of the challenges facing PV energy is to reduce the time and costs related to administrative processes, interconnection, as well as addressing planning and zoning issues. As a follow-up to the ARET study Dr. O'Neill and Dr. Irizarry led a rooftop solar challenge project under DOE's SunShot Initiative. Three graduate students and six undergraduate students participated in this project. The team identified, analyzed, and provided best practices that could overcome processing and planning obstacles that impede a faster growth of rooftop PV systems. All the recommendations presented in the final report would have a great impact on Puerto Rico's PV market; for example, implementation of fast evaluation and interconnection ("plug and play rules") for small rooftop PV systems ${ }^{14}$. Nevertheless, as stated before, the challenge is not purely technical. The dominant energy model is one that favors a central, hierarchical organization of the electric industry, with little (if any) public participation. That dominant energy model also favored one way of planning and operating the electric infrastructure owned by the people of Puerto Rico. These legacy practices require a major energy transformation effort, not just physical, but also organizational and social. A step towards that transformation occurred on December 2014, when the state utility regulator (created on May 2014) adopted many of the recommendations from this rooftop report for use in the regulation of distributed generation and net metering.

Dr. O'Neill and Dr. Irizarry delved further into the energy policy process to contribute more directly to the search and implementation for solutions to Puerto Rico's energy challenges.

\section{Working to Transform the Energy Policy Regime from Within}

The experiences described thus far could be framed in ways other than policy entrepreneurship. Nevertheless, the argument put forward in this paper is that in order for engineers to contribute to energy transformations, a capacity building process (experiences and interdisciplinary exchanges) needs to take place. Even Dr. José Colucci, who was an early policy entrepreneur, received training and had experience in entrepreneurship while working in industry before becoming a university professor. Through their interactions with social scientists and many energy initiatives, Dr. O'Neill and Dr. Irizarry went from participating in policy efforts as consultants to becoming active policy entrepreneurs: expanding capacities, broadening horizons and affecting the policy regime towards energy transformations. They were ready when the policy window opened in Puerto Rico, when the energy challenges were so large that "the established systems were inadequate and required major transformative changes"1. Thus the policy entrepreneur traits mentioned earlier in this paper accurately describe the actions of these engineering professors. 


\section{A. Policy Advising}

Dr. O’Neill worked as Senior Advisor to the Governor of Puerto Rico on Energy from 2013 to 2014. His main task was to work on an energy plan with the following objectives: a framework for the reform of the electric power industry, a culture of conservation and efficiency, promotion of energy autonomy, mass transportation and fuel substitution for vehicles. The energy context in Puerto Rico is difficult. For years there was a lack of planning, integration or continuity of energy strategies and technologies. It has been extremely difficult to unify diverse sectors behind an energy policy that could withstand political party changes in government. Changes in energy policy directions have been an obstacle for decades to approach the local energy challenges from a holistic perspective, and to implement truly sustainable energy strategies and alternatives. In order to achieve integrated planning policies that ensure sustainable development, a paradigm shift in energy policy was needed: the state's energy policy was redefined as a continuous process of planning, inquiry, execution, evaluation and improvement of all energy issues.

During March and April 2013, Dr. O’Neill organized and conducted five town hall meetings on three locations around Puerto Rico to receive input and suggestions about the energy plan directly from citizens. Over 300 persons participated of these meetings, and important recommendations were made. Suggestions from the town hall meetings, from participants of other public presentations, as well as meetings and reports from key stakeholders informed two executive orders that supported the energy plan implementation. One of the orders created an Energy Autonomy Advisory Board to work on the energy plan with a clear vision of energy sustainability. The other executive order created an Electric Reliability Advisory Board to recommend actions to ensure the safe and reliable interconnection and operation of utility-scale renewable energy. Dr. O’Neill acted as president of both advisory boards.

A key resource for this policy work was the participation of a team led by Dr. O'Neill in a "Policy Academy" sponsored by the National Governors Association (NGA). Dr. O'Neill wrote a proposal for Puerto Rico's participation in the Academy, and the Island was selected along with three other U.S. jurisdictions to receive energy policy support from NGA (seminars, invited speakers, sponsored travel to workshops). This activity ran from October 2013 to June 2014 and it allowed the team to create executable actions in areas such as conservation, efficiency, biofuels, and utility business models. Those actions were to be implemented by the Puerto Rico energy office.

From all the energy tasks, the main priority for Dr. O'Neill was the transformation of the electric power sector, directed by PREPA since 1941. A comprehensive review of the state law that gives direction to the electric power sector had not happened in 73 years (as a public power company, there is a state law that created PREPA). The work from NGA's policy academy provided important support to the effort of transforming the electric power industry. The Energy Autonomy Advisory Board was essential in analyzing documents, reports, recommendations and in drafting specific recommendations to be included in a bill to holistically amend laws related to the electricity sector.

After the bill was presented, it was combined with other power industry reform bills. On May 2014, the Governor signed into law the most comprehensive reform of Puerto Rico's electric power sector since 1941: Act 57-2014. Although the law is not perfect, it does give the sector a 
new policy direction: to promote a sustainable future, maximizing benefits and minimizing impacts (economic, environmental and social), to support renewable energy, conservation and efficiency, as well as transparency and citizen participation. During the process that ended in the signing of the law, Dr. O'Neill had to use all the skills and knowledge as energy researcher, all the past experiences as Director of ITEAS and Coordinator of the Energy Roundtable, his background as energy consultant for cities and communities, the lessons learned from UPRM ethics and social science colleagues in order to face the challenging political process surrounding the electric power reform discussions. This actual policy experience proved the effectiveness of the ITEAS capacity building process in preparing a person to be an effective policy entrepreneur and to deal with the complexities of energy transformations.

\section{B. Transforming the Electric Utility}

Dr. Irizarry joined PREPA's Board of Directors in 2012 as representative of the consumers. This is a position that requires winning an election held among utility consumers. He became President of the Audits Committee 5 months into his two-year term. The Audits Committee oversees the utility's Internal Auditor Office (IAO) an office within the utility that responds directly to the Board of Directors. The first task was to appoint a new Chief Auditor, the previous one had retired, and to receive and approve/modify the Internal Auditor Office work plan for the next year. During the next 2 years the Committee directed the IAO to perform an extensive audit of the fuel procurement, receiving (including testing) and payment process.

The utility spends $\$ 2.6$ billion per year in fuel and local newspapers published stories where individuals alleged wrongdoing in the fuel procurement process. As elected representative of the consumer in the Board Dr. Irizarry was compelled to inform, thru the press, of on-going efforts while keeping his fiduciary duty not to disclose confidential information that could harm the audit or the purchasing of fuel (skewing the market). The skills used by engineering professors in their day-to-day task of presenting complex issues and information to an audience of learners was extremely valuable to accomplish the task of communicating with the press. The use of graphs, tables and diagrams was invaluable to succinctly present the process, the findings and the recommended actions.

The same experience, on the usefulness of being trained as a professor to present to the general public (e.g., AARP meetings, small community gatherings across the state, Chamber of Commerce, etc) or professional audiences (e.g., the State Society of Professional Engineers) repeated again and again in topics ranging from the price of electricity, environmental impact, managing the (large) debt of the public corporation, and thorny political issues like taxes on the electricity to pay for City government expenses. A good number of these presentations found their way, after adaptation to the subject at hand, into Dr. Irizarry's courses and seminars to students and student associations at UPRM (Board member duties accounted for half of his academic load, although for the first year the policy work was on top of a 12-credit semester load). Dr. Irizarry was a respected and well-regarded board member, earning the position of Vice-President of the Board (the first time a consumer representative held that position). His expertise also earned him a place in the Electric Reliability Advisory Board mentioned earlier, and was constantly called by the Governor's office to request his expert opinions. The results of his policy entrepreneurial work are further evidence of the importance of some level of policy instruction, such as the one received within ITEAS. 


\section{Return to Academia}

The engineering policy entrepreneurs returned to UPRM during 2014. Their policy experiences enrich their engineering teaching and research work every day. For example, a significant portion of the material used for press interviews was then modified and incorporated in Dr. Irizarry's course "Power System Analysis" when discussing the topic of fossil fire generation, fuels and economic dispatch. Students' reaction was extremely positive as they could relate the topic being discussed in class with the articles they had read in the local papers. An interesting effect was noted: students were becoming "insiders" through the professor's experience and through his comments augmenting the newspaper stories.

Another on-going work influenced by their policy work is the study of microgrids. Microgrids allow a region to operate independently from the power grid or connect to the grid when needed. The authors are studying the technical feasibility and social implications of allowing community microgrids. This is an instance where technical, social and policy issues are studied simultaneously to formulate recommendations that take advantage of microgrids, while truly contributing to sustainability. A National Science Foundation grant is currently providing funds for this project, that includes computer scientists and social scientists in the study of ways to design, build and operate sustainable smart grids. The goal is to get closer to a new open access distribution system based on microgrids and distributed generation.

Issues related to the evaluation and reward system have surfaced as part of their reflections on the experiences in the policy area. Although the evaluation and promotion process at UPRM accounts for "Actively participating in professional or civic associations" and "participating in public service" (under the "General Evaluation Module") and "Enriches his/her teaching using his/her professional experiences" (under the "Education Module") these are a very small percentage of the evaluation, $6.3 \%$ and $6.9 \%$, respectively, of each Professor's Evaluation Module. There is, for all intends and purposes, no recognition or reward in the promotion process for educators who want to actively participate in public service. The benefits to society, being represented by a subject matter expert that can communicate complex issues in a simple albeit complete manner to the general public, and the benefits to the educator from the experience, bringing real life issues to be connected and integrated into the topics covered in class, deserve greater reward in the evaluation process of a professor that works more actively in local or state policy issues.

\section{Worforce Development and Outreach}

The authors are using the policy experiences presented in this paper to study ways to structure learning activities that provide opportunities to UPRM students, professionals and the general public to be exposed to policy issues. The professional formation of engineers, and the energy literacy of the general public, has much to benefit from this policy-based learning approach.

One of the policy areas that both engineering professors identified as an opportunity for improvement was the capacity of stakeholders to effectively engage in technical discussions of energy issues. The policy framework mentioned in Section II strives among other things to improve the knowledge/data of stakeholders and their capabilities to communicate ideas; as well as to provide opportunities for networking/learning within the jurisdiction and to introduce new 
concepts to frame debates. All these actions were part of the stakeholders' preparation to influence energy policy. The engineering professors identified the need to better structure outreach and workforce development activities to ensure their effectiveness for energy policy capacity building.

UPRM is part of the Center for Grid Engineering Education (GridEd), which is a consortium of utilities and universities led by the Electric Power Research Institute (EPRI). GridEd is supported by a DOE grant to develop educational and workforce development material to shape the future power distribution grid. Preferences regarding topics and format of energy education activities were collected as part of the written evaluation of the September 2014 kick-off seminars held in two locations in Puerto Rico: one in the western side of the Island and another in the eastern side. The seminars had over 200 participants; a total of 153 completed and returned the surveys (79 in site 1, 74 in site 2$)$. The audiences were mostly engineers (91\% in Site 1, 82\% in Site 2$)$. The audiences were split among private, government or self-employed (mostly consultants). Between 9 and $11 \%$ of the audience were students. Table $\mathrm{V}$ shows the percentages per sector per location.

Table V. Audience distribution by type of employer

\begin{tabular}{|c|c|c|}
\hline Sector & $\begin{array}{c}\text { First } \\
\text { site }\end{array}$ & $\begin{array}{c}\text { Second } \\
\text { site }\end{array}$ \\
\hline Private & $23 \%$ & $45 \%$ \\
\hline Government & $30 \%$ & $12 \%$ \\
\hline Own business & $39 \%$ & $34 \%$ \\
\hline Other & $9 \%$ & $11 \%$ \\
\hline
\end{tabular}

About $92 \%$ in each location expressed they would participate in on-line short courses or seminars (Table VI). The preferred type of activity at both sites is the one-day short course (either accounting individual selection, or adding the "any option" selections). The 3-hour seminar also had good support. Table VII shows stronger opposition to two-day courses In Site 2, whereas in Site 1 the 2-day short course had more support (42\% found this alternative "acceptable").

Finally, the top topics of interest are ordered in Table VIII in order of support. The level of interest of each location is shown for each location, where 1 is the top topic. The surveys were pretty clear on the top five topics: Renewable Generation Technologies, PV Systems, Energy Efficient Technologies, Renewable Integration Challenges: transmission vs distribution, and Energy Storage. These preferences have already been used in the schedule of seminars and other workforce development activities delivered through the project. Topics such as energy storage, new battery technologies and distributed energy sources were part of the 2015-2016 activities. 
Table VI. Distribution of format preference

\begin{tabular}{|c|c|c|}
\hline Type of activity & $\begin{array}{c}\text { First } \\
\text { site }\end{array}$ & $\begin{array}{c}\text { Second } \\
\text { site }\end{array}$ \\
\hline Short course (1 day) & $43 \%$ & $49 \%$ \\
\hline Short course (2 days) & $8 \%$ & $3 \%$ \\
\hline Seminar (3 hours) & $15 \%$ & $33 \%$ \\
\hline Any option & $34 \%$ & $15 \%$ \\
\hline
\end{tabular}

Table VII. Preference on short course length

\begin{tabular}{|c|c|c|}
\hline Length of activity & $\begin{array}{c}\text { First } \\
\text { site }\end{array}$ & $\begin{array}{c}\text { Second } \\
\text { site }\end{array}$ \\
\hline Not 2 days & $58 \%$ & $83 \%$ \\
\hline 2 days acceptable & $42 \%$ & $17 \%$ \\
\hline 1 day acceptable & $85 \%$ & $67 \%$ \\
\hline
\end{tabular}

Table VIII. Top topics of interest by location

\begin{tabular}{|c|c|c|}
\hline Topics & $\begin{array}{c}\text { First site } \\
\text { rank }\end{array}$ & $\begin{array}{c}\text { Second } \\
\text { site rank }\end{array}$ \\
\hline $\begin{array}{c}\text { Renewable Generation } \\
\text { Technologies }\end{array}$ & 1 & 2 \\
\hline Solar Photovoltaic Systems & 2 & 1 \\
\hline $\begin{array}{c}\text { Energy Efficient Technologies } \\
\text { Renewable Integration } \\
\text { Challenges: transmission vs } \\
\text { distribution }\end{array}$ & 3 & 3,4 \\
\hline
\end{tabular}




\section{A New Regulatory Course in Electrical Engineering}

The policy experiences of the engineering professors revealed a need for qualified personnel to face the challenges related to the changes in the utility regulatory regime in Puerto Rico (as per Act 57-2014). A new course "Regulatory Issues in Electrical Engineering" was created and taught in the Fall of 2015 to address this need. This is a survey course on regulatory processes at the federal and state level with emphasis on telecommunications, energy, biomedical and electronic applications. The courses on public policy and social issues described earlier, as well as the professors' experiences working directly within the policy regime, helped identify the key topics to include in the course as well as the time to allot as shown on Table IX.

Table IX. Topics for the course "Regulatory Issues in Electrical Engineering"

\begin{tabular}{|l|c|}
\hline \multicolumn{1}{|c|}{ Topics } & Contact Hours \\
\hline Fundamentals and purpose of electrical engineering regulation & 8 \\
\hline Overview of ratemaking & 2 \\
\hline History of electrical engineering regulation in US \& PR & 2 \\
\hline $\begin{array}{l}\text { Summary of U.S. laws and federal jurisdiction relevant to electrical } \\
\text { engineering }\end{array}$ & 2 \\
\hline $\begin{array}{l}\text { Introduction to the main federal agencies relevant to regulation of } \\
\text { electrical engineering areas: FCC, NTIA, EPA, FERC, U.S. Patent Office, } \\
\text { FDA }\end{array}$ & 6 \\
\hline $\begin{array}{l}\text { Discussion of key electrical engineering technical standards granting } \\
\text { organizations: ANSI, IEEE, UL, NIST }\end{array}$ & 3 \\
\hline $\begin{array}{l}\text { Overview of patent and intellectual property issues in electrical } \\
\text { engineering }\end{array}$ & 2 \\
\hline Summary of relevant laws in Puerto Rico & 3 \\
\hline $\begin{array}{l}\text { Electrical engineering regulatory entities in Puerto Rico: } \\
\text { Telecommunications Regulatory Board, Environmental Quality Board, } \\
\text { Planning Board, Energy Commission, Permit Management Office (OGPe) }\end{array}$ & 7 \\
\hline Consumer advocacy organizations and NARUC & 3 \\
\hline $\begin{array}{l}\text { Critical electrical engineering infrastructure: examples of location, } \\
\text { operation and security issues }\end{array}$ & 2 \\
\hline Regulatory trends: challenges and opportunities & 3 \\
\hline Exam & 2 \\
\hline Total hours & 45 \\
\hline
\end{tabular}

The students completed two projects as part of the course. They selected the topic, completed a literature search and looked for potential ways to apply the ideas in Puerto Rico. Some examples of students' projects were:

- Ratemaking for distribution systems with distributed generation

- Wheeling of electric power

- Demand response as a service

- Wind energy, environment and society 
The course was well received by the students. An assessment instrument was used to identify aspects from the course that needed improvement and to verify if the course objectives were achieved. Tables X and XI summarize the main findings of the course assessment. Student perception is well aligned to the professor's evaluation as shown in Table X.

Table X. Attainment of course objectives for "Regulatory Issues in Electrical Engineering"

\begin{tabular}{|c|c|c|}
\hline $\begin{array}{c}\text { Assessment Question } \\
\text { Did the course achieve the following } \\
\text { objectives: }\end{array}$ & $\begin{array}{c}\text { Results } \\
\text { (student perceptions) }\end{array}$ & $\begin{array}{c}\text { Results } \\
\text { (professor) }\end{array}$ \\
\hline $\begin{array}{l}\text { Study regulatory processes related to } \\
\text { telecommunications, energy, biomedical and } \\
\text { electronic applications (state and federal). }\end{array}$ & Objective completely met & $86 \%$ \\
\hline Introduction to state regulatory processes & Objective met & $88 \%$ \\
\hline Introduction to federal regulatory processes & Objective completely met & $88 \%$ \\
\hline $\begin{array}{c}\text { Student should be able to understand the } \\
\text { forces that shape and influence electrical } \\
\text { engineering regulatory decisions }\end{array}$ & Completely agree & $92 \%$ \\
\hline $\begin{array}{c}\text { Student should be able to search and } \\
\text { understand the engineering-related } \\
\text { literature. }\end{array}$ & Completely agree & $84 \%$ \\
\hline
\end{tabular}

In terms of course objectives, the course met every goal. A student suggested that the time devoted to state regulatory process could be extended. Regarding impact on student career options (Table XI), students expressed the course opened new possibilities to them and motivated them to be mindful of state regulatory issues, especially those related to energy. General comments about the course included a recommendation for more debate sessions, to keep inviting guest speakers, to reduce the federal regulatory section in order to increase the state regulatory processes. Some students suggested teaching some of the topics at the undergraduate level. Student input is essential and will be used to improve the course for the next time. From the professor's perspective, the challenge was the usual: course contents vs. interactive opportunities. Also, since it was the first time this specific course was taught, the professor had to fine-tune topics, coverage, time and student participation.

Table XI. Course impact on student career options

\begin{tabular}{|c|c|}
\hline Assessment Item & Results \\
\hline $\begin{array}{c}\text { Students will be able to contribute to the regulatory challenges in the } \\
\text { state (energy and telecommunication Regulatory) }\end{array}$ & Agreed \\
\hline $\begin{array}{c}\text { Students are motived to continue learning about regulatory topics or } \\
\text { pursue a career on this area }\end{array}$ & $\begin{array}{c}\text { Completely } \\
\text { agreed }\end{array}$ \\
\hline $\begin{array}{c}\text { The course motivated students to act in a different way or look at their } \\
\text { career options differently }\end{array}$ & Agreed \\
\hline Students think the course topics will be relevant in their future jobs & Agreed \\
\hline
\end{tabular}




\section{A Solar Community}

Since January 2015, Dr. O’Neill has been collaborating with an economically challenged community in the Southern side of Puerto Rico. The community has a goal of turning their community into a sustainable one. He has been helping them in various aspects related to energy. He delivered an energy efficiency seminar to the community, and has participated in meetings with community leaders. From those meetings emerged the idea of a pilot PV project in the community's meeting center. The pilot project is not intended to be only a technological gadget, but a holistic effort that includes efficiency as well as the study of energy use patterns in the community. A first step towards that goal was a preliminary study of the potential of the community to become a "solar community". With support from the DOE grant (GridEd), Dr. O'Neill supervised three students in a capstone design project. The students completed an initial design for the PV system in the community's meeting and common area, as well as scenarios of PV penetration within the community. The professor and the students met with community members during the Spring of 2015 to ensure their work was aligned with community needs and objectives. On May 2015 the final report was presented to the community. The community leaders used that student report for a proposal submitted in December 2015 to acquire funds to continue developing their goal of a solar community. Once the community proposal is funded, the first stage would be a series of workshops on topics such as electricity fundamentals, renewable energy, and energy patterns to provide the community with the basic knowledge to effectively engage in discussions and activities to build their solar community. Thus, this collaboration is also aligned to the policy framework described in Section II. Dr. O'Neill helped with the proposal writing and will deliver at least three of those workshops as part of the outreach efforts of GridEd. There are preliminary plans to repeat this collaboration with a second community in the Northern end of Puerto Rico, including exploring the feasibility of a community microgrid.

\section{Lessons Learned: Impact of Policy Work in Engineering Education}

Engineers are formed to solve so-called "technical problems" and are usually given an isolated general education that does not prepare them well to address real-world challenges effectively outside the norms of traditional engineering practice. And yet, while there is widespread recognition that the complex problems they face today require a different set of skills, mainstream-engineering curricula is not providing the holistic preparation required. Graduates are expected to make connections among diverse knowledge areas, and many times struggle because they do not have the necessary tools to effectively engage professionals in other fields. Integrating energy policy in electrical engineering curriculum can result in better methods to enable graduates to collaborate with non-engineering experts in the path towards a sustainable future. Efforts of such integration at UPRM have been described in this paper. Such integration is not limited to courses; the curriculum also includes projects in and out of the classroom, as well as outreach activities. Table XII shows the impact of actual policy work in the way policy topics were integrated in various educational, workforce development and outreach activities at UPRM. 
Table XII. Activities before and after faculty participation in state policy processes.

\begin{tabular}{|c|c|c|}
\hline & Before & After \\
\hline Courses & $\begin{array}{l}\text { Public Policy in Electrical Engineering } \\
\text { (EE); Social, Ethical and Social Issues in } \\
\text { EE: Overview courses on general issues in } \\
\text { public policy, social impact, sustainability. }\end{array}$ & $\begin{array}{l}\text { Regulatory Issues in EE: A course } \\
\text { more focused on the needs of the } \\
\text { regulatory environment in Puerto } \\
\text { Rico. }\end{array}$ \\
\hline $\begin{array}{c}\text { Community } \\
\text { projects }\end{array}$ & $\begin{array}{l}\text { Casa Pueblo PV Laboratory: One of the } \\
\text { first attempts to directly influence the } \\
\text { policy regime. }\end{array}$ & $\begin{array}{l}\text { Solar communities: Capacity building, } \\
\text { broadening the policy horizon within } \\
\text { a community. This could become a } \\
\text { standard to be followed by other } \\
\text { communities in Puerto Rico. }\end{array}$ \\
\hline Projects & $\begin{array}{l}\text { ARET: traditional university-based } \\
\text { consulting, that pointed out the need of a } \\
\text { more holistic approach to energy resource } \\
\text { assessment. } \\
\text { Rooftop Challenge: Broadening the policy } \\
\text { horizon, this project intended to influence } \\
\text { the policy regime by supporting an } \\
\text { increase in PV systems in Puerto Rico. }\end{array}$ & $\begin{array}{l}\text { DOE and NSF grants that include a } \\
\text { vital policy component. Align the } \\
\text { technological tasks of the projects } \\
\text { with key social and policy aspects. } \\
\text { Better aligned with goals of } \\
\text { influencing the policy regime. }\end{array}$ \\
\hline Outreach & $\begin{array}{c}\text { Continuing Education for professional } \\
\text { societies, community seminars and high } \\
\text { school demonstrations: traditional } \\
\text { outreach efforts mainly for capacity } \\
\text { building. }\end{array}$ & $\begin{array}{l}\text { Through a DOE project, outreach } \\
\text { activities are better structured to } \\
\text { empower participants to broaden their } \\
\text { own scopes of actions. Support } \\
\text { individuals and communities in efforts } \\
\text { to influence the policy regime. }\end{array}$ \\
\hline
\end{tabular}

XIII. Conclusions

More participation from engineering faculty in public policy issues can improve decision-making regarding complex issues. Engineering professors can be essential in shedding light to instances were "powerful and wealthy vested interests" minimize or dismiss terrible environmental and social injustices ${ }^{17}$. Faculty participation in the public arena provides rich professional development opportunities while also allowing universities, especially state-funded institutions, to better serve the constituents that support them. Integrating energy policy activities in engineering curriculum can result in better methods to enable graduates to collaborate with non-engineering experts in the path towards a sustainable future. For engineering educators to be successful as policy entrepreneurs, they need to establish collaborations with non-engineering disciplines (e.g., the social sciences) in order to achieve a basic foundation of policy theory and practices. 
This paper summarized the process of capacity building and broadening policy horizons that allowed two UPRM engineering professors to integrate policy in various academic activities as well as to become active energy policy entrepreneurs in Puerto Rico. The policy actions from engineering professors and students contributed towards important energy policy transformations in the Island. Although their experience is somewhat outside the norm, it shows a process through which engineers can be effective participants in policy processes. But such participation could be as simple as discussions on compliance with federal regulations (e.g., EPA, FDA), activities of citizen outreach for public works or depositions before city councils. At the very least, every engineer will be part of a community, and an exposure, even if brief, to policy issues can have a long-lasting impact on how that engineer shares his/her knowledge in society and becomes a better citizen.

\section{Acknowledgments}

The pioneering energy leadership and work of Dr. José Colucci is acknowledged as an inspiration to the work described in this paper. Partial support from the Center for Grid Engineering Education, a DOE grant under the GEARED initiative, is also acknowledged (http:/grided.epri.com/).

\section{References}

[1] Mintrom, M. and Norman, P. "Policy Entrepreneurship and Policy Change," The Policy Studies Journal, vol. 37, no. 4, 2009, pp. 649-667.

[2] Kingdon, J. Agendas, Alternatives and Public Policies, Little, Brown \& Co. Boston, 1995 (original from 1984).

[3] Cohen M.D., March J.G. and Olsen J.P. "A Garbage Can Model of Organizational Choice,” Administrative Science Quarterly, 17 (1), 1972, pp. 1-25.

[4] Krugman, P. Peddling Prosperity: Economic Sense and Nonsense in an Age of Diminished Expectations, W. W. Norton \& Company, 1994.

[5] Cohen, N. and Naor, M. "Reducing dependence on oil? How policy entrepreneurs utilize the national security agenda to recruit government support: The case of electric transportation in Israel," Energy Policy, vol. 56, 2013, pp. 582-590.

[6] Cobb, R and Elder, C. "Communication and Public Policy," Handbook of Political Communication (D. Nimmo, K. Sanders, editors), Sage, 1981.

[7] Timmermansa, J., van der Heidenb, S., Born, M. "Policy entrepreneurs in sustainability transitions: Their personality and leadership profiles assessed," Environmental Innovation and Societal Transitions. vol. 13, 2014, pp. 96-108.

[8] Meijerink, S and Huitema, D. "Policy Entrepreneurs and Change Strategies: Lessons from Sixteen Case Studies of Water Transitions around the Globe," Ecology and Society, vol. 15, no. 2, 2010.

[9] O'Neill-Carrillo, E., Ortiz-García, C., Pérez, M., Baigés, I., Minos, S. "Experiences with Stakeholder Engagement in Transitioning to an Increased Use of Renewable Energy Systems," Proceedings of the IEEE International Symposium on Sustainable Systems and Technology, Washington, DC, May 2010. 
[10] O’Neill-Carrillo, E., Pérez-Lugo, M., Ortiz-García, C., Irizarry-Rivera, A., Colucci-Ríos, J. "Sustainable Energy: Balancing the Economic, Environmental and Social Dimensions of Energy," Energy 2030: IEEE Conference on Global Sustainable Energy Infrastructure, Atlanta, GA, 2008.

[11] Lindquist, E., Discerning policy influence: Framework for a Strategic Evaluation of IDRC Supported Research. School of public administration, University of Victoria, Victoria, 2001.

[12] O’Neill-Carrillo, E., Zamot, R., Hernandez, M., Irizarry, A. "Beyond Traditional Power Systems: Energy Externalities, Ethics and Society," Proceedings of the IEEE 2012 International Symposium on Sustainable Systems and Technology (ISSST), Boston, MA. May 2012.

[13] Irizarry Rivera, A., Colucci-Ríos, J., O’Neill-Carrillo, E. Achievable Renewable Energy Targets, Report to quantify local renewable energy potential, 300 pages, 2009, available at http://www.uprm.edu/aret/

[14] O’Neill-Carrillo, E., Figueroa, A., Irizarry, A. Improved Permitting and Interconnection Processes for Rooftop PV Systems in Puerto Rico, Book based on final Sunshot project report to DOE, 145 p. 2013.

[15] O’Neill-Carrillo, E, Seijo, L., Hirleman, E., Maldonado, F., Marti, E., Rivera, A. "Mentoring Interdisciplinary Service Learning Projects," Proceedings of the $37^{\text {th }}$ Frontiers in Education Conference (FIE 2007), Milwaukee, MN, October 2007.

[16] The Energy Roundtable website (in Spanish). Available at http://iteas.uprm.edu/mesa.html

[17] Home-Douglas, P. “Off-Campus Crusaders,” PRISM, ASEE, March-April 2016, pp. 24-37. 